\title{
Analisis Perlindungan Hukum Terhadap Tindak Kekerasan pada Anak di Indonesia
}

\author{
Alycia Sandra Dina Andhini', Ridwan Arifin² \\ Fakultas Hukum Universitas Negeri Semarang, Semarang. \\ Email : ${ }^{1}$ alyciasandra23@gmail.com, ${ }^{2}$ ridwan.arifin@mail.unnes.ac.id
}

Info Artikel:

| Diterima: 12 Februari2019

| Disetujui: 01 Juli 2019

| Dipublikasikan: 02 Juli 2019

\begin{abstract}
Violence against children in Indonesia from time to time continues to occur and increasingly various forms. In fact, children are the successors and assets owned by the nation that will maintain and realize the ideals of the nation. Pindakan is a behavior that violates the law and will be given sanctions to the perpetrators who do this. At present many crimes are often carried out such as violence. Violence is an arbitrary act carried out by someone with the aim of hurting physically and psychologically. Parents have an important role to maintain and protect but actually acts of violence against children are carried out by their closest people like parents. Then the need for a way so that acts of violence against children are not continuously carried out and must be given firm action by the government to the perpetrators who did this. This paper examines how legal protection efforts for children as victims of violence that occurred in Indonesia.
\end{abstract}

Keywords: Children, Crime, Violence, Handling Violence, Legal Protection

\begin{abstract}
Abstrak
Kekerasan terhadap anak di Indonesia dari waktu ke waktu terus terjadi dan semakin beragam bentuknya. Padahal, anak merupakan penerus dan aset yang dimiliki oleh bangsa yang akan mempertahankan, serta mewujudkan cita-cita bangsa. Tindak pindana merupakan perilaku yang melanggar hukum dan akan diberikan sanksi kepada pelaku yang melakukan hal tersebut. Saat ini banyak tindak pidana yang sering dilakukan seperti kekerasan. Kekerasan merupakan tindakan sewenang-wenang yang dilakukan oleh sesorang dengan tujuan menyakiti fisik maupun psikis. Orang tua memiliki pernan penting untuk menjaga dan melindungi tetepi justru tindak kekerasan terhadap anak dilakukan oleh orang terdekatya seperti orang tua. Maka diperlukannya cara agar tindakan kekerasan terhadap anak tidak terus menerus dilakukan dan harus diberikan tindakan yang tegas oleh pemeritah kepada pelaku yang melakukan hal tersebut. Tulisan ini mengkaji tentang bagaimana upaya perlindungan hukum terhadap anak sebagai korban kekerasan yang terjadi di Indonesia.
\end{abstract}

Kata Kunci: Anak, Tindak Pidana, Kekerasan, Penanganan Kekerasan, Perlindungan Hukum 
A. PENDAHULUAN

\begin{abstract}
Negara Kesatuan Republik
Indonesia (NKRI)merupakan salah satu negara yang berlandaskan pada dasar hukum (rechtstaat), tidak berlandaskan pada dasar kekuasaan (machtstaat). Hal tersebut sudah dijelaskan pada UndangUndang Dasar Negara Republik Indonesia Tahun 1945 pasal 1 ayat 3 yang membahas tentang "Negara Indonesia adalah negara hukum. ${ }^{1}$ Negara Indonesia merupakan negara hukum, maka negara Indonesia menginginkan supaya ditegakkannya hukum oleh semua masyarakat Indonesia. Maksudnya, setiap perlakuan yang diperbuat maka harus berdasarkan denganaturan-aturan hukum yang berlaku.
\end{abstract}

Pengertian dari hukum yaitu suatu rangkaian yang berisikan peraturanperaturan terkait dengan perilaku seseorang sebagai anggota masyarakat, dan bertujuan untuk mewujudkan kebahagiaan, keselamatan, serta mewujudkan ketertiban pada kehidupan masyarakat. Setiap individu masyarakat memiliki macam-macam kepentingan, maka untuk memenuhi kepentingan tersebut setiap anggota masyarakat harus melakukan hubungan yang diatur oleh hukum untuk mewujudkan suatu keseimbangan yang terdapat di dalam masyarakat. $^{2}$

Negara Indonesia Sebagai Negara hukum memiliki tujuan, dalam undangundang dasar 1945 dijelaskan bahwa Negara Kesatuan Republik Indonesia memiliki tujuan yaitu Negara akan melindungi segenap bangsa Indonesia dan tumpah darah Indonesia, memajukan kesejahteraan umum, mencerdaskan

Edi Suharto, 2015, "Kekerasan Terhadap Anak Respon Pekerja Sosial", Jurnal Kawistara, Vol 5 No. 1, hlm 43-45.

2 Maidin Gultom, 2010, Perlindungan Hukum Terhadap Anak Dalam Sistem Peradilan Pidana Anak di Indonesia, Bandung: PT Refika Aditama, hlm 3 . kehidupan bangsa, serta ikut melaksanakan dalam perdamaian dunia berdasarkan kemerdekaan, perdamaian abadi dan keadilan sosial.

Negara Kesatuan Republik Indonesia memiliki tujuan tersebut dengan maksud jika hak-hak masyarakat yang dijamin dan dapat melindungi masyarakat pada setiap kehidupannya. Tetapi, kenyataanya yang terjadi di masyarakat dikit demi sedikit sudah bertolak belakang dengan tujuan nengara yang sudah dijelaskan dalam undang-undang dasar 1945. Saat ini, berbagai macam permasalah hukum mulai bermunculan. Perilaku manusia juga sudah semakin bertolak belakang dengan norma-norma yang ada di dalam kehidupanmasyarakat sehingga dapat terjadi pelanggaranpelanggaran tindak pidana atau kejahatan.

Pengertian kejahatan yaitu suatu kenyataan yang ada didalam kehidupan masyarakat dan harus perhatian secara khusus. Hal ini tidak hanya disebabkan karena kejahatan yang dari hari ke hari semakin berkembang, tetapi kejahatan juga dapat menyebabkan keresahan atau gangguan bagi ketertiban didalam masyarakat.Contoh dari kejahatan yang sering terjadi di dalam kehidupan masyarakat yaitu tindakan kekerasan. Kekerasan adalah suatu perilaku sematamata yang dilakukan sesorang terhadap orang lain dengan tujuan untuk menyakiti mapun melukai psikis maupun fisik. Tindak pidana seperti ini sering diperlakukan terhadap orang-orang yang lemah seperti anak-anak maupun wanita. Tetapi bersamaan dengan berkembangnya zaman. Kenyataannya dalam kehidupan masyarakat tidak hanya anak saja yang menjadi korban. ${ }^{3}$

Joanne, 1985, "The Children of Divorce Intervention Program: An Investiogation of the Efficacy of a School-Based Prevention Program", Journal of Consulting and Clinical Psychology, Vol 53 No. 5, hlm 603-611. 
Anak merupakan makhluk sosial yang membutuhkan bantuan orang lain untuk menggembangkan kemampuannya, karena anak terlahir dengan segala kelemahan maka jika tidak ada bantun darui orang lain anak tersebut tidak dapat mencapai pada taraf manusia yang normal. Dalam perkembangannya anak membutuhkan kasih sayang dari orangorang terdekatnya. Anak juga mempunyai pikiran, perasaan dan kehendak tersendiri. Hal tersebut salh satu dari totalitas psikis dan merupakan sifat-sifat yang berbeda dio setiap tipe-tipe perkembangan saat masa anak-anak. ${ }^{4}$ Anak merupakan salah satu asset yang dimiliki oleh suatu bangsa, anak memiliki peran sebagai successor suatubangsa. Di Indonesia anak merupak penerus cita-cita perjungan bangsa. Peran strategis ini sudah disadari oleh masyarakat Internasional untuk mewujudkan sebuah konvensi yang menekankan posisi anak sebagai mahkhluk sosial yang harus mendapatkan perlindungan atas hahak yang dimilikinya. $^{5}$

Di Indonesia terdapat beberapa fakta yang memprihatinkan masih banyak anak-anak yang mendapatkan tindakan kekerasan. Di Indonesia tindak kekerasan dapat dilakukan dimana saja seperti di jalanan, di sekolah hingga di dalam rumah tangga. Hal ini dapat menimbulkan secara tidak sadar anak berkonflik dengan hukum. ${ }^{6}$ Kekerasan anak yang terjadi di dalam rumah tangga dapat melibatkan

4 Anonim, Pengertian Anak sebagai Makhluk Sosial,

http://www.duniapsikologi.com/pengertian-anaksebagai-makhluk-sosial , diakses pada tanggal7 Desember 2018.

5 Anonim, Anak dan Aset Bangsa, http://www.koran-jakarta.com/anak-aset-bangsa/, diakses pada tanggal 7 Desember 2018.

6 Wiwik Subekti, Sosialisasi dan Komunikasi Terkait dengan Pemberdayaan Perempuan dan Perlindungan Anak, http://bali.bkkbn.go.id/ViewArtikel.aspx?ArtikelI $\underline{D}=423$, diakses pada tanggal 7 Desember 2018. orang terdekat dari anak tersebut seperti ibu, ayah, atau saudara-saudara yang lainnya. Kekerasan anak yang terjadi dirumah tangga juga sering terjadi karena adanya tekanan ekonomi yang dialami oleh orang tua sehingga tidak dapat memenuhi kebutuhan anggota keluarganya. Sebagai orang tua pendidikan yang ditempuh oleh anak merupakan hal yang paling utama, agar anak tidak terpengaruh dengan lingkungan yang tidak kondusif sehingga dapat memicu anak tersebut untuk melakukan tindak melanggar hukum seperti tindak kekerasan. Menteri pendidikan dan kebudayaan juga menyampaikan bahwa model video-video game haru menjadi perhatian orang tua. $^{7}$

Semua macam tindakan kekerasan yang dilakukan kepada anak perlu untuk ditangani atau dicegah sebagaimana yang sudah dijelaskan dalam Undang-Undang Republik Indonesia Nomor 23 Tahun 2002 yang membahas terkait dengan perlindungan anak. Anak harus mendapatkan perlindungan dan dipenuhi haknya untuk tumbuh dan berkembang secara normal, dan anak harus diberi kesempatan untuk mengikuti secara optimal untuk mendapatkan perlindungan dari tindak kekerasan.saat ini anak juga sudah menjadi pelaku dari tindakan kekerasan yang melanggar hukum ini. ${ }^{8}$

Maka dari itu, masalah-masalah terkait dengan anak yang berhubungan dengan hukum wajib untuk diselesaikan dengan baik untuk mendapatkan perlindungan hak anak sehingga bisa menjadi sumber daya manusia (SDM)

Rohma Siti, 2005, “Atribusi Kekerasan Dalam Rumah Tangga, Kesadaran terhadap Kesetaraan Gender dan Strategi Menghadapi Masalah Pada Perempuan Korban Kekerasan Rumah Tangga”, Jurnal Psikologi, Vol 32 No.1, hlm 34-46.

$8 \quad$ Siti Maryam, 2017, "Gambaran Pendapatan Orang Tua dan Kekerasan pada Anak dalam Keluarga di Gampong Geulanggang Teungoh Kecamatan Kota Juang Kabupaten Bireuen', Psikodimensi, Volume 16, Nomor 1, hlm 1-7. 
Indonesia yang memiliki kualitas tinggi. Atas dasar tersebut, sehingga kepedulian atau perhatian yang ditujukan kepada anak dijelaskan dalam bentuk Undang-Undang Nomor 11 Tahun 2012 yang membahas mengenai sistem peradilan pidana anak sebagi pengganti dari Undang-Undang Nomor 3 Tahun 2012 yang membahas mengenai pengadilan anak. Penggantian Undang-Undang tersebut perlu dilakukan jika dengan alasan Undang-Undang lama yang sudah tidak releven lagi dengan kebutuhan hukum yang ada didalam kehidupan masyarakat.

Diberlakukannya Undang-Undang yang baru saja di revisi memilik tujuan untuk mewujudkan sebuah keadilan yang benar-benar dapat menjamin perlindungan kepentingan yang terbaiuk untuk anak yang sedang berhadapan dengan hukum. Memberikan sanksi pidana adalah pilihan yang terakhir, sehingga dalam penerapan Undang-Undang baru lebih menekankan model restorative justice memiliki maksud untuk memulihkan ke kondisi awal perlu diutamakan cara yang lain diluar pengadilan. Seperti dengan melakukan cara diversi, cara diversi merupakan suatu cara untuk mengalihkan agar penyelesaian perkara anak dari proses yang diselesaikan di pengadilan menjadi proses yang diselesaikan diluar pengadilan. Diversi juga merupakan salah satu jalan keluar agar anak tidak dibawa ke pengadilan. Maka diversi dapat menangani anak-anak yang menghadapi masalah yang berkaitan dengan hukum meski di tingakatan penyidik, penuntutan maupun tingkatan pemeriksa perkara yang dilakukan di pengadilan. ${ }^{9}$

Seharusnya lembaga pengak hukum atau lembaga yang berwenang memberikan hukuman yang adil untuk pelaku tindak pidana kekerasansupaya

M. Nasir Djamil, 2013, Anak Bukan Untuk Dihukum dalam Catatan Pembahasan Sistem Peradilan Anak, Jakarta Sinar Grafika, hlm 6. hukum benar-benar didirikan dan diwujudkan dengan adil dalm kehidupan masyarakat. Tetapi lembaga yang menegakan hukum harus memperhatikan pertimbangan yang lebih relevan untuk mengambil suatu keputusan saat memberikan hukum untuk pelaku pidana yang masih anak-anak. Karena hukuman tidak hanya diharapkan untuk memberi sanksi jera terhadap pelaku yang masih anak-anak supaya tidak mengulangi perbuatannya serta untuk mencegah orang-orang untuk melakukan hal yang sama, tetapi juga harus memperhatikan anak-anakkarena yang sudah dijelaskan pada Undang-Undang (UU) Tahun 2012 Nomor 11 yang membahas mengenai Sistem Peradilan Pidana Anak.

\section{B. METODE PENELITIAN}

Penulisan ini menggunakan pendekatan yuridis normatif, sebab penulis hanya mengkaji dan menganalisis berdasarkan dari kasus-kasus yang sudah ada sebelumnya yang diperoleh baik dari media cetak, surat kabar, majalah, jurnal, ataupun media online, yang kemudian dianalisis menggunakan peraturan perundang-undangan dan teori hukum yang terkait. Penulisan ini fokus pada perlindungan hukum terhadap anak dalam kasus kekerasan di Indonesia.

\section{PEMBAHASAN}

\section{Tindak Pidana Kekerasan dalam Dimensi Hukum Pidana}

Dalam kamus bahasa

Indonesia tindak pidana memiliki arti perbuatan yang melanggar hukum dan pelakunya akan diberi hukuman pidana. $^{10}$ Menurut Moeljatno kata "perbuatan" biasanya sering digunakan seperti perbuatan jahat, perbuatan cabul ataupun perbuatan

10 Wirjono Prodjodikoro, 2003, Asas-Asas Hukum Pidana di Indonesia, Bandung, Refika Aditama, hlm 59. 
yang melanggar hukum. Kemudian Moeljatno mengatakan bahwa:
a. Yang dimaksud dilarang merupakan perbuatan yang dibuat oleh manusia yakni suatu keadaan yang disebabkan oleh perilaku seseorang maksudnya larangan tersebut ditujukan kepada perilakunya. Sedangkan orangnya di beri ancaman pidana.

b. Larangan (yang ditujukkan untuk perilakunya) diberi ancaman pidana (ditujukan untuk orang yang melakukannya) terdapat hubungan yang erat, maka itu perilaku (yang merupakan

c. Untuk mengatakan terdapat hubungan yang erat maka lebih tepat dipakai istilah perbuatan pidana, pengertian yang luas menunjukkan pada dua keadaan yang konkrit yakni pertama terdapat kejadian tertentu dan kedua terdapat orang yang melakukan atau menyebabkan kejadian tersebut. ${ }^{11}$

Maka, menurut Moeljatno tindak pidana yaitu perilaku yang dilarang oleh hukum dan anak diberi sanksi pidana kepada siapa saja yang melakukannya atau melanggar hukum.Satochid Kartanegara saat rangkain kuliahnya menggunakan kata tindak pidana untuk strafbaar feit. Karena kata tersebut mencakup arti seperti ini "berbuat atau melakukan dan pengertian tidak melakukan suatu perbuatan, tidak berbuat ". Kata tindakan sebagai starfbaar feitlebih baik dipakai karena kata ini mudah diterima oleh masyarakat. Tindakan pidana merupakan suatu perbuatan yang tidak boleh dilanggar oleh suatu peraturan hukum dan akan diberi sanksi jika melanggar.

11 Moeljatno, 2009, Asas-Asas Hukum Pidana, Jakarta, Rineke Cipta, hlm 58-60.
Kemudian dari segi bahasa kekerasan berasal dari kata "keras". Pada Kamus Besar Bahasa Indonesia kekerasan memiliki arti perbuatan yang dilakukan oleh seseorang atau kelompok yang dapat menimbulkan cedera atau meninggalnya orang lain dan bisa juga menimbulkan kerusakan pada barang orang lain atau fisik orang lain.Kekerasan merupakan suatu ancaman atau menggunakan kekuatan fisik untuk menyebabkan kerusakan terhadap orang lain. Berhubungan dengan tindakan kekerasan, teori sosial menyatakan jika anaka dapat mempelajari tentang perilaku manusia yang baru melalui pengamatannya yang nyata terhadap orang lain.Seiring berjalannya waktu kekerasan mejadi budaya atau perilaku yang terusmenerus dilakukan di kalangan masyarakat Indonesia hingga saat ini dapat merubah nilai kepribadian bangsa maupun seseorang.

Kekerasan juga sudah melekat dengan kehidupan masyarakat, untuk menyelesaikan konflik selalu saja diikuti dengan tindakan kekerasan. Tindakan kekerasan yang sering dilakukan tidak hanya dilakukan oleh anggota masyarakat saja tetapi saat ini tindak kekerasan juga dilakukan oleh aparatur sipil negara. Menurut Johan Galtung kekerasan dibagi menjadi tiga yakni kekerasan kulturul, kekerasan secara langsung, dan kekerasan struktural. Kekerasan struktural yaitu sebuah proses dan kekerasan kultural merupakan sesuatu yang memiliki sifat tetap atau permanen, sedangkan kekerasan secara langsung yakni sebuah peristiwa yang terjadi secara langsung.

Jika dilihat dari sifatnya kekerasan dibagi menjadi dua yaitu kekerasan strukural dan kekerasan personal. Kekerasan struktural memiliki sifat yang statis, kemudian 
kekerasan struktural memperlihatkan stabilitas tertentu dan tidak kelihatan. Bentuk-bentuk kekerasan structural sepertifragmentasimasyarakat,eksploit asi,penetrasikekuatan yang menghilangkanotonomi daerah dan hilangnya solidaritas. Sedangkan kekerasan personal memiliki sifat yang dinamis, mudah untuk diamati dan dapat mewujudkan perubahan. ${ }^{12}$

Erich from menjelaskan tentang teori kekerasan jika kekerasan dapat dilihat dari segi instingtifisik. Teori ini merupakan sebuah analisis yang memahami tentang perilaku agresi manusia adalah tindakan yang lepas dari aspek sosial budaya sekelilingnya. Teori ini sama seperti dengan yang dikatakan oleh Freud bahwa agresivitas merupakan suatu insting yang dibantu dengan kekuatan yang alami dan agresivitas tidak hanya ditentukan dengan lingkungan eksternal saja.

\section{Kekerasan Terhadap Anak}

Kekerasan anak memiliki istilah abuse yang memiliki arti kekerasan penganiayaan, perlakuan yang salah atau penyiksaan. Kekerasan terhadap anak merupakan perilaku yang sengaja dan berdampak bahaya untuk anak-anak secara fisik maupun psikisnya. Istilah dari child abuse yakni macam-macam tingkah laku, dari perilaku ancaman yang dilakukan secara langsung oleh orang yang lebih dewasa. ${ }^{13}$ Sedangkan Barker menjelaskan jika kekerasan terhadap anak merupakan tindakan

12 Justin Sihombing, 2005, Kekerasan Terhadap Masyarakat Marjinal, Yogyakarta: Penerbit Narasi, hlm 8-9.

13 Khaled H. Nadaa and El Daw A. Suliman, 2010, "Violence, Abuse, Alcohol and Drug Use and Sexual Behaviors in Street Children of Greater Cairo and Alexandria", AIDS: Journal Wolters Kluwer Health, Vol. 24 No. 2, hlm 42. yang dilakukan secara berulang-ulang dengan tujuan untuk melukai fisik maupun psikis kepada anak melalu hasrat dan desakan, hukuman badan yang sudah tidak terkendali, pembullyan ataupun kekerasan seksual terhadap anak. Kekerasan terhadap ini justru sering dilakukan oleh orang tua yang seharusnya meratawat anak tersebut. ${ }^{14}$

Kekerasaan anak biasanya berawal dari pengabaian hingga ke pemerkosaan dan pembunuhan. Terry E Lawson mengatakan bahwa kekerasan terhadap anak dibedakan menjadi empat macam yakni verbal abuse, emotical abuse, sexual abuse dan physical abuse. Sedangkan Suharto membedakan kekerasan terhadap anak menjadi empat juga yaitu kekerasan psikologis, kekerasan fisik, kekerasan sosial hingga kekerasan seksual. Keempatnya dapat dijelasn sebagai berikut :

a. Kekerasan psikologis yakni kekerasan yang meliputi seperti mengeluarkan atau berbicar dengan bahasa yang tidak sopan bisa di sebut dengan kata-kat kasar atau kotor, memberikan atau memperlihatkan video, gambar maupun buku yang memiliki unsure ponografi kepada anak. Anak yang menerima tindakan tersebut akan menimbulkan anak menjadi pemalu, takut bertemu dengn orang-orang asing hingga menangis jika didekati dengan orang asing.

b. Kekerasan fisik yakni berupa pemukulan, penganiyaan, dan penyiksaan kepada anak-anak

14 Flanagan Kelly dkk, 2012, "The Potential of Forgiveness as a Respinse For Coping With Negative Peer Exsperiences", Journal of Adolenscence, Vol.35, hlm 1215-1233. 
memakai benda-benda tertentu. Perilaku ini memiliki dampak seperti adanya luka fisik hingga mengalami kematian pada anak.

c. Kekerasan sosial salah satu contohnya penelantaran anak. Pengertian penelantaran adalah perilaku orang tua terhadap anak yang tidak memberi kehidupan maupun perhatian yang layak pada masa perkembangan anak tersebut.

d. Kekerasan seksual salah satunya seperti tindakan prakontrak seksual yang dilakukan oleh orang dewasa terhadap anakanak dengan melakukan sentuhan atau memperlihatkan gambar visual. ${ }^{15}$

Pada pembuatan UndangUndang No. 23 Tahun 2002 yang dijelaskan diatas didasari oleh peratifikasian Konvensi Hak Anak pada tahun 1990. Kemudian pasal 1 angka 1 Undang-Undang No. 23 Tahun 2002 menjelaskan bahwa anak merupakan seseorang yang masih dibawah umur 18 tahun, termasuk anak yang masih di dalam perut sang ibu. Pasal ini mencakup sangat luas karena anak yang belum lahir kedunia atau masih didalam perut ibu sudah memiliki perlindungan hukum.

\section{Faktor dan Dampak Kekerasan Terhadap Anak}

Kekerasan terhadap anak memiliki penyebab mengapa tindakan yang melanggar hukum ini bisa terjadi, menurut Suharto kekerasan terhadap anak disebabkan dari beberapa faktor yakni faktor internal maupun faktor eksternal. Penyebab tersebut sebagai berikut:

15 Noviana, 2015, "Kekerasan Seksual Terhadap Anak: Dampak dan Penanganannya", Jurnal Sosio Informa, Vol 1 No. 1, hlm 13-28 a. Faktor ekonomi seperti kemiskinan keluarga, penghasilan tidak memenuhi, memiliki banyak anak maupun orang tuang yang menganggur.

b. Keluarga yang mengalami perceraian.

c. Menikah dini atau keluarga yang belum matang secara psikologis hal tersebut menjadikan ketidaktauan bagaimana cara untuk mendidik anak maupun anak yang lahir diluar nikah.

d. Gangguan mental yang dialami oleh orang tua bisa juga sebagai penyebab tindakan kekerasan terhadap anak.

e. Nasib yang diterima oleh orang tua saat masa kecil ditelantarkan cenderung melakukan tindakan yang salah terhadap anaknnya.

f. Kondisi lingkungan yang buruk. ${ }^{16}$ Selain Suharto, Rusmil memiliki mendapat jika tindakan kekerasan terhadap anak terjadi karena berbagai hal dan di bagi menjadi tiga yakni:

a. Faktor dari orang tua atau keluarga

Orang tua memiliki peranan yang sangat penting jika terjadi tindakan kekerasan terhadap anak. Faktor yang menyebabkan mengapa orang tua melakuan tindakan kekerasan tersebut yakni:

1) Pemabuk atau pengkonsumsi obat-obatan.

2) Mengalami ganguan mental.

3) Dibesarkan dengan kekerasan.

4) Belum matang dalam hal fisik maupun emosional. 
5) Praktik budaya yang merugikan anak.

b. Faktor dari lingkungan

Faktor dari lingkungan dapat menyebabkan tindakan kekerasan terhadap anak. Lingkungan merupakan faktor dan keadaan yang dapat mempengaruhi kehidupan anak. Faktor lingkungan yang bisa menyebabkan terjadinya tindakan kekerasa terhadap anak yaitu:

1) Terdapatnya sebuah anggapan yang mengatakan jika anak merupakan milik orang tua sendiri.

2) Konsisi sosial ekonomi yang sangat rendah.

3) Kemisikinan yang ada di dalam masyarakat.

4) Kedudukan wanita yang di anggap rendah.

5) Masyarakat yang individualis.

c. Faktor Individu

Faktor individu biasanya terjadi karena perilaku yang menyimpang terhadap anak tersebut dan anak mengalami gangguan perkembangan seperti memiliki penyakit. Parton dan Moore mengatakan jika factor individu merupakan faktor penyebab yang sering terjadi. ${ }^{17}$ Kemudian kekerasan terhadap anak memiliki dampak yang sangat besar, berikut dampak yang dialami oleh anak karena mendapatkan tindak kekerasan:

17 Timpka T, dkk, 2015, "Protocol Design for LargeScale Cross-Sectional Studies of Sexcual Abuse and Associated Factors in Individual Sport", Journal of Sport Science and Medecine, Vol. 14 No. 1, hlm 179-187, online pada https://www.ncbi.nlm.nih.gov/pmc/articles/PMC4 306771/ a. Kerusakan pada fisik atau cacat.

b. Kegagalan dalam bidang pendidikan.

c. Gangguan terhadap psikologi anak.

d. Menjadi pemabuk atau dapat mengkonsumsi obatobatan.

e. Agresif.

f. Kematian. ${ }^{18}$

\section{Perlindungan Terhadap Anak}

Pada tahun 1979 pemerintah meresmikan suatu peraturan yang ditujukan kepada anak-anak untu meletakkan ke sebuah lembaga proteksi yang memiliki keamanan. Peraturan disebut diatur dalam Undang-Undang No. 4 Tahun 1979 yang membahas tentang kesejahteraan untuk anak. Seorang anak yang tidak dirawat dengan baik oleh orang tuanya bisa berdampak pembatalan hak asuh untuk orang tua itu sendiri. Kemudian pemerintah menetapkan undangundang pengadilan khusus anak dengan tujuan agar bisa memberikan perlindungan kepada anak yang sedang berhadapan dengan masalah hukum dan akan tetap memperoleh hak-haknya. Pemerintah juga menetapkan undang-undang tahun 2003 No.23 yang membahas tentang perlindungan terhadap anak.

Hak asasi anak merupaka sebagaian dari hak asasi manusia (HAM) yang diatur dalam undangundang dasar negara republik Indonesia 1945 (UUD 1945). Dilihat dari sisi kehidupan berbagsa dan bernegara anak merupakan bagian dari intergral sebuah negara, anak juga menjadi generasi mudah yang akan

18 Ogunkan DV, 2014, "Public Perception of Street Children in Ibadan Nigeri", Journal IFE Pyschologia, Vol 22 No.1, hlm 39-49. 
meneruskan dan mewujudkan cita-cita bangsa. Sehingga anak memiliki hak untuk kehidupannya, tumbuh, berkembang dan mengikuti secara optimal hak-haknya atas perlindungan dari semua macam tindakan kekerasan. $^{19}$

Indonesia merupakan negara yang menjunjung tinggi hak asasi manusianya (HAM) dan sudah diatur dalam Undang-Undang No. 39 Tahun 1999 selain itu juga diatur dalam Undang-Undang No. 23 Tahun 2002, undang-undang tersebut membahas tentang hak asasi manusia dan perlindungan untuk anak yang secara subtansi sudah cukup untuk mengakomodir hak-hak anak.

Kemudian agar perlindungan anak dapat berhasil dilakukan seperti yang dirumuskan pada UndangUndang No.23 Tahun 2001, perlindungan hukum untuk kehidupan anak memiliki berbagai syarat sebagai berikut:

a. Nilai budaya untuk perkembangan anak.

b. Solidaritas yang dibangun setiap individu.

c. Faktor ekonomi dan sosial. ${ }^{20}$

Secara umum perlindungan terhadap anak dibagi menjadi dua yakni perlindungan yang bersifat yuridis dan perlindunga yang bersifat nonyuridis. Perlindungan yang mermiliki sifat yuridis merupakan sebuah perlindungan yang mencakup semua peraturan hukum yang dapat mengatur kehidupan anak tersebut. Sedangkan, perlindungan dengan sifat nonyuridis meliputi bidang kesehatan, bidang pendidikan dan bidang sosial. ${ }^{21}$

\section{PENUTUP}

Tindak pidana merupakan suatu perbuatan yang melanggar aturang sudah ditetapkan oleh pemerintah atau disebut dengan hukum dan akan diberikan sanksi pidan bagi pelaku yang melakukan tindakan hukum, kekerasan merupakan suatu perbuatan sewenang-wenang yang bertujuan untuk melukai orang lain fisik maupun psikis. Seiring berkembangnya zaman kejahatan atau tindak pidana semakin banyak bermunculan contohnya tindak pidan kekerasan kepada anak. Saat ini orang tua yang memiliki peranan untuk melindungi anak sudahlah tidak ada artinya lagi bahkan saat ini orang tua merupakan pelaku tindak kekerasan terhadap anak sendiri. ada beberapa alasan mengapa orang tua sudah tidak jadi pelindung bagi anak salah satuny akrena factor ekonomi, keluarga yang tidak harmonis dan ganguan mental yang dialami oleh orang tua. Kekerasaan yang dilakukan kepada anak menimbulkan beberapa dampak seperi anak menjadi terganggu dalam bidang pendidikannya, anak menjadi agresif hingga kematian karena kerusakan fisik yang dialami oleh anak.
19 Riris Eka Setiani, 2016, "Pendidikan Anti Kekerasan Untuk Usia Dini Konsepsi dan Implementasinya", Golden Age Jurnal Ilmiah Tumbuh Kembang Anak Usia Dini, Vol. 1 No. 1 April 2016, hlm 39, online pada http://ejournal.uin-

suka.ac.id/tarbiyah/index.php/goldenage/article/vie w/1254/1154 (39-56)

20 Hasanah Uswatun, 2015, "Penanganan Kekerasan Anak Berbasis Masyarakat",Social Work Jurnal, Vol. 6 No. 1, hlm 1-153.
21 Dirk John, 2010, "Dampak Tindakan Kekerasan Terhadap Perempuan dan Anak Serta Solusinya", Jurnal Sasi, Vol 16 No. 3, hlm 12-15. 


\section{DAFTAR PUSTAKA}

\section{Buku \& Jurnal}

Djamil, M. Nasir. Anak Bukan Untuk Dihukum dalam Catatan Pembahasan Sistem Peradilan Anak. Jakarta: Sinar Grafika. 2013.

Gultom, Maidin. Perlindungan Hukum Terhadap Anak Dalam Sistem Peradilan Pidana Anak di Indonesia. Bandung: PT Refika Aditama. 2010

Joanne. "The Children of Divorce Intervention Program: An Investiogation of the Efficacy of a School-Based Prevention Program". Journal of Consulting and Clinical Psychology. Vol 53 No. 5, hlm 603-611. 1985.

John, Dirk. "Dampak Tindakan Kekerasan Terhadap Perempuan dan Anak Serta Solusinya". Jurnal Sasi. Vol 16, No. 3. 2010.

Kelly, Flanagan dkk. "The Potential of Forgiveness as a Respinse for Coping with Negative Peer Exsperiences". Journal of Adolenscence, Vol. 35, No. 5. 2012.

DOI:

https://doi.org/10.1016/j.adolescence.201 2.04 .004

Maryam, Siti. "Gambaran Pendapatan Orang Tua dan Kekerasan pada Anak dalam Keluarga di Gampong Geulanggang Teungoh Kecamatan Kota Juang Kabupaten Bireuen". Psikodimensi, Volume 16, Nomor 1. 2017.

Moeljatno. Asas-Asas Hukum Pidana. Jakarta: Rineke Cipta. 2009.

Nadaa, Khaled H. dan El Daw A. Suliman. "Violence, Abuse, Alcohol and Drug Use and Sexual Behaviors in Street Children of Greater Cairo and Alexandria". AIDS: Journal Wolters Kluwer Health. Vol 24 No. 2, 2010. Retrieved online pada https://pdfs.semanticscholar.org/4274/3ea 314652f9e3dd50e8955539a5e00974b63.p df

Noviana. "Kekerasan Seksual Terhadap Anak: Dampak dan Penanganannya", Jurnal Sosio Informa.Vol 1 No. 1, 2015.

Ogunkan DV. "Public Perception of Street Children in Ibadan Nigeri".Journal IFE Pyschologia, Vol. 22 No.1, 2014.
Prodjodikoro, Wirjono. Asas-Asas Hukum Pidana di Indonesia. Bandung: Refika Aditama. 2003.

Purwoko T. "Analisis Faktor-Faktor Penyebab Keberadaan Anak Jalanan di Kota Balikpapan”. Jurnal Sosiologi, Vol 1 No. 4, 2013.

Rohma, Siti. "Atribusi Kekerasan Dalam Rumah Tangga, Kesadaran terhadap Kesetaraan Gender dan Strategi Menghadapi Masalah Pada Perempuan Korban Kekerasan Rumah Tangga”. Jurnal Psikologi, Vol. 32 No.1, 2005.

Setiani, Riris Eka. "Pendidikan Anti Kekerasan Untuk Usia Dini Konsepsi dan Implementasinya".Golden Age Jurnal Ilmiah Tumbuh Kembang Anak Usia Dini, Vol. 1 No. 1 April 2016, hlm 3956, online pada http://ejournal.uinsuka.ac.id/tarbiyah/index.php/goldenage/a rticle/view/1254/1154

Sihombing, Justin. Kekerasan Terhadap Masyarakat Marjinal. Yogyakarta: Penerbit Narasi. 2005.

Suharto, Edi. "Kekerasan Terhadap Anak Respon Pekerja Sosial", Jurnal Kawistara, Vol 5 No. 1, Tahun 2015. DOI: https://doi.org/10.22146/kawistara.6403, online pada https://jurnal.ugm.ac.id/kawistara/article/v iew/6403/5051

Timpka T, dkk. "Protocol Design for Large-Scale Cross-Sectional Studies of Sexcual Abuse and Associated Factors in Individual Sport", Journal of Sport Science and Medecine, Vol. 14 No. 1, hlm 179-187, Tahun 2015. Retrieved online pada https://www.ncbi.nlm.nih.gov/pmc/article s/PMC4306771/

Uswatun, Hasanah. "Penanganan Kekerasan Anak Berbasis Masyarakat".Social Work Jurnal, Vol. 6 No. 1, hlm 1-153, Tahun 2015.

\section{Peraturan Perundang-Undangan}

Republik Indonesia. Undang-Undang Dasar Negara Republik Indonesia Tahun 1945

Republik Indonesia. Undang-Undang No. 11 Tahun 2012 Nomor 11 tentang Sistem Peradilan Pidana Anak.

Republik Indonesia. Undang-Undang Nomor 3 Tahun 2012 tentang Pengadilan Anak 
Republik Indonesia. Undang-Undang Nomor 4 ttahun 1979 tentang Kesejahteraan Anak

\section{Website :}

Anonim, Pengertian Anak sebagai MakhlukSosial, http://www.duniapsikologi.com/pengertia n-anak-sebagai-makhluk-sosial, diakses pada tanggal 7 Desember 2018.

Anonim, Anak dan Aset Bangsa, http://www.koran-jakarta.com/anak-asetbangsa/, diakses pada tanggal 7 Desember 2018.

Subekti, Wiwik. Sosialisasi dan Komunikasi Terkait dengan Pemberdayaan Perempuan dan Perlindungan Anak, https://bulelengkab.go.id/detail/artikel/sos ialisasi-dan-komunikasi-terkait-denganpemberdayaan-perempuan-danperlindungan-anak-11, diakses pada tanggal 7 Desember 2018. 
